类

\title{
PAISAGENS: UMA CONTRIBUIÇÃO DA ARTE PARA A GEOGRAFIA SOCIOCULTURAL
}

\author{
- MARIA GERALDA DE ALMEIDA ${ }^{1}$ \\ ${ }^{1}$ lesa/UFG. E-mail para contato: galmeida@ufg.br
}

Recebido em:

Aprovado em:

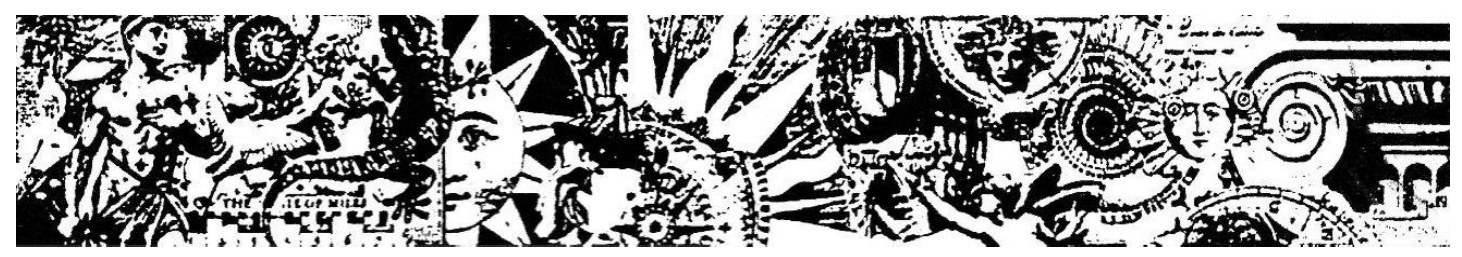

Resumo: Este artigo realiza uma leitura da paisagem aproximando a geografia sociocultural da arte. A reflexão apresenta brevemente os paisagistas que se destacaram na arte, com uma transformação da concepção de natureza, e cunharam o termo paisagem, apropriado pela geografia. Além disso, uma discussão sobre imagens, imaginação e imaginário beneficia o entendimento da criação e dos usos da paisagem, sobretudo na geografia sociocultural. Na atualidade, o homem é saturado de imagens decorrentes de novas técnicas e de satélites. E está em curso uma crise de representação de paisagem arquetípica, cuja imagem não tem correspondência com a paisagem real.

Palavras-Chave: natureza; teorias de arte; imagem; imaginário; imaginação.

\section{LANDSCAPES: ART'S CONTRIBUTION TO SOCIOCULTURAL GEOGRAPHY}

ABSTRACT: THIS ESSAY IS A READING INTO LANDSCAPE THAT ASSOCIATES IT TO A SOCIOCULTURAL GEOGRAPHY OF ART. THE REFLECTION BRIEFLY PRESENTS ART'S PROMINENT LANDSCAPERS THAT HOLD A CONCEPTION OF NATURE THAT WAS THE BASIS TO GEOGRAPHY'S APPROPRIATION OF THE TERM LANDSCAPE. IT ALSO DISCUSSES HOW IMAGENS, IMAGINATION AND IMAGINARY BENEFITS THE COMPREHENSION OF LANDSCAPE CREATION AND USES, PARTICULARLY IN SOCIOCULTURAL GEOGRAPHY. NOWADAYS, MAN IS SATURATED BY IMAGENS DECURRENT FROM NEW TECHNICS AND SATELLITES. THERE IS A CRISIS IN THE REPRESENTATION OF ARCHETYPAL LANDSCAPE DUE TO ITS NON-CORRESPONDENCE WITH REAL LANDSCAPES. 
KEYWORDS: NATURE; ART THEORY; IMAGE; IMAGINARY; IMAGINATION.

\section{PAISAJES: UNA CONTRIBUCIÓN DEL ARTE A LA GEOGRAFÍA SOCIOCULTURAL}

RESUMEN: ESTE ARTÍCULO EFECTÚA UNA LECTURA DEL PAISAJE QUE SE APROXIMA LA GEOGRAFÍA SOCIOCULTURAL DEL ARTE. LA REFLEXIÓN PRESENTA BREVEMENTE LOS PAISAJISTAS QUE DESTACARON EN EL ARTE, CON UNA TRANSFORMACIÓN DE LA CONCEPCIÓN DE LA NATURALEZA, Y ACUÑAN EL TÉRMINO PAISAJE, APROPIADO POR LA GEOGRAFÍA. ADEMÁS, UNA DISCUSIÓN SOBRE IMÁGENES, IMAGINACIÓN E IMAGINARIO BENEFICIA LA COMPRENSIÓN DE LA CREACIÓN Y LOS USOS DEL PAISAJE, ESPECIALMENTE EN LA GEOGRAFÍA SOCIOCULTURAL. LA SOCIEDAD ESTÁ SATURADA DE IMÁGENES RESULTANTES DE NUEVAS TÉCNICAS Y SATÉLITES. Y SE ESTÁ LLEVANDO A CABO UNA CRISIS DE REPRESENTACIÓN DEL PAISAJE ARQUETÍPICO, CUYA IMAGEN ES DIFERENTE DEL PAISAJE REAL.

PALABRAS CLAVE: NATURALEZA; TEORÍAS DEL ARTE; IMAGEN; IMAGINARIO; IMAGINACIÓN.

\section{Iniciando}

Arte é um termo que tem desafiado tanto os filósofos quanto os artistas na sua definição e no seu conceito. Desde o século XIX a geografia dela se aproximou por meio da arte pictórica.

Contudo, não é a geografia, no seu senso lato, a se interessar por ela, sendo especificamente o domínio da geografia sociocultural, que se distingue como aquela da expressão de necessidades biológicas e de exigências espirituais. A geografia sociocultural é das materialidades, das imaterialidades, do visível e, também, aquela do invisível e das ideias. Em outras palavras, entendem-se os geógrafos dessa geografia sensível como criadores de artes.

O termo paisagem ora é um conceito, ora uma palavra com muitos significados e ora um objeto. Tal ambiguidade é registrada, porém, neste artigo, o destaque privilegia paisagens de pintores e de geógrafos socioculturais. Neste estudo, pretende-se discutir as vertentes e as semelhanças que propiciaram diálogos entre a Geografia e a Arte. Ele, portanto, busca desenvolver uma reflexão sobre a relação da arte e da paisagem tendo a natureza e as ações humanas, o imaginário e a imaginação, como fator conector.

De acordo com Grison (2000), a arte é a escrita criativa do espaço. Assim, compositores, pintores, escritores são tanto produtores do espaço quanto usuários do espaço. Eles reproduzem, projetam, narram o espaço em um processo de construção/desconstrução.

Para alguns, a arte é um conceito que distingue as coisas identificáveis 
compreendidas numa extensão e que devem possuir propriedades comuns que não existem naquelas que são externas ao conjunto. A dificuldade de definir arte está na sua direta relação e dependência com a conjuntura histórica e cultural que a faz surgir, fato que fica aqui registrado, sem o devido aprofundamento, por não ser esse o propósito desta discussão.

A arte engloba todas as criações realizadas pelo ser humano, expressando uma visão sensível de mundo. Ela busca ver o seu entorno com outros olhares, ou seja, culmina numa interpretação crítica e reflexiva sobre o mundo e seus eventos e nos traz uma multiplicidade de significados personificados por meio de obras que possuem uma enorme carga simbólica. A arte, além de possuir caráter simbólico, dialoga com o lugar, com o espaço, bem como expressa e reflete a cultura por meio da simbologia que a expressa.

Nesse contexto, a arte pode vir a ser uma importante via de compreensão, para a geografia, da relação ser humano-natureza em um determinado espaço, em um dado período histórico, uma vez que a expressão artística, além de ser uma expressão individual, é também a manifestação de uma dada cultura. Sem dúvida, a arte confere uma identidade territorial às pessoas e ao lugar em que é feita.

\section{Abordagens para entender e criar arte}

Cabe relembrar que a arte se utiliza de uma pluralidade de linguagens, tais como: arquitetura, desenho, escultura, pintura, escrita, música, dança, teatro e cinema, em suas diversas combinações. Para Pinheiro et al. (2016), ela consiste em uma atividade humana que se relaciona às manifestações estéticas realizadas por artistas ao usarem suas emoções, ideias e percepções. Resumidamente, ela serve para provocar o estímulo aos sentidos e à consciência dos espectadores, dos contempladores e do público de modo geral.

A própria definição de arte é dinâmica, é uma construção cultural variável e sem significado constante. Até numa mesma época e numa mesma cultura pode haver múltiplas acepções do que é arte. Também, a preocupação de melhor entender e mesmo interpretar a arte encontra-se nas diversas teorias que foram criadas. Não discutirei todas que a balizam, mas as principais serão brevemente apresentadas, auxiliando no propósito de desvelar a paisagem na geografia sociocultural e na arte pictórica.

A Teoria Institucional da Arte, na década de 1960, teve seu surgimento pelo filósofo George Dickie. Ele defende que não se pode encontrar uma definição para o 
conceito da arte, em sentido classificativo, generalizando características de sistemas artísticos particulares, tampouco generalizando os critérios do que foi considerado histórica e esteticamente como boa arte.

Assim, sob o pano de fundo heterogêneo da arte contemporânea, Dickie desenvolve a "teoria institucional da arte", que privilegia metodologicamente o contex to cultural em que um objeto é instaurado como arte em detrimento das suas propriedades intrínsecas. Para ele, arte é aquilo a que se atribui um conjunto de aspectos eleitos por uma comunidade de especialistas que confere estatuto de arte às obras. Uma das críticas feitas a essa teoria é justamente o fato de ela não explicar todo o processo que alça um objeto ao mundo da arte. Também, uma objeção adicional seria a de que a teoria institucional é viciosamente circular. Obras de arte são definidas como objetos que são aceitos como tais pelas pessoas que entendem de arte; e as pessoas que entendem de arte são definidas como as que aceitam certos objetos como sendo obras de arte. Essa teoria ainda goza de larga aceitação no contex to artístico.

Nas décadas de 1970/1980, outra teoria ganha impulso, a Simbólica da Arte. Destaca-se, nessa teoria, o filósofo Nelson Goodman. Nela, a arte funciona como símbolo estético. Uma questão metodológica específica parece brotar do modelo estético de Goodman, em especial a questão de que a arte não é uma cópia da realidade, pois o artista não está e nem poderia estar isento das categorias convencionais de representação. $\mathrm{O}$ que o artista faz quando pinta um quadro não é a cópia de uma realidade, mas, antes, é a construção de um novo modelo de realidade.

Isso nos permite dizer que a arte não imita a realidade, mas, pelo contrário, a arte constrói modelos de realidade. A geografia já procura interpretar a realidade e a compreender essas pseudorrealidades. Para Cauquelin (2005), a estética não tem nada a ver com o "gosto", o "belo" e o "único", mas, antes, seu papel é mostrar o modo como a arte constrói modelos de realidade e se torna uma atividade cognitiva. Ainda nessa abordagem simbólica, Carmo (2015) destaca que a posição de Goodman parece promissora não apenas no que diz respeito a ressaltar o papel cognitivo da arte, mas, sobretudo, por evidenciar a importância dos sistemas simbólicos enquanto critérios de correção para as nossas práticas mais corriqueiras.

Em fins da década de noventa, no século XX, ganha impulso a antiteoria da Arte. U. Eco, filósofo e crítico literário, seu maior expoente, afirmava que a obra de arte só existe em sua interpretação, na abertura de múltiplos significados que pode ter para o observador. Seu livro A Definição da Arte, originalmente publicada em 1968 (2014) é 


\section{9:}

referência na compreensão da história da estética, sobretudo no que diz respeito às relações entre a filosofia da arte, desde a segunda metade do século passado. Para Eco, a estética não pode ser dissociada em diferentes ramos - não há uma "estética da pintura" ou uma "estética do cinema”. Em Obra Aberta (1962), o autor ajudou a romper com a ideia de que um objeto artístico é algo acabado, com uma interpretação única e fechada ditada pelo artista. Essa crítica, de "um novo modo de entender a relação com a obra e sua fruição por parte do público", seria, posteriormente, aceita. Essas teorias não se anulam com o surgimento de novas propostas de abordagens. Elas se superpõem, imbricam-se e continuam presentes.

Concluindo esta breve discussão sobre a arte, retomo: qual o laço que a geografia tem com a arte pictórica? E com a imaginação? Os homens são portadores de representações, eles fazem representações, eles têm intenções. Estas últimas explicam a quantidade de práticas espaciais. Um lugar existe pela presença nele de pessoas, e então tudo se mistura: sentimentos, memórias individuais e coletivas, discursos, mobilidades. E, se arte é a escrita criativa do espaço, é inegável que ela se irmana com a geografia, que busca interpretar e explicar o espaço. E a cartografia permanece uma interpretação da realidade entre arte e geografia (figura 1).

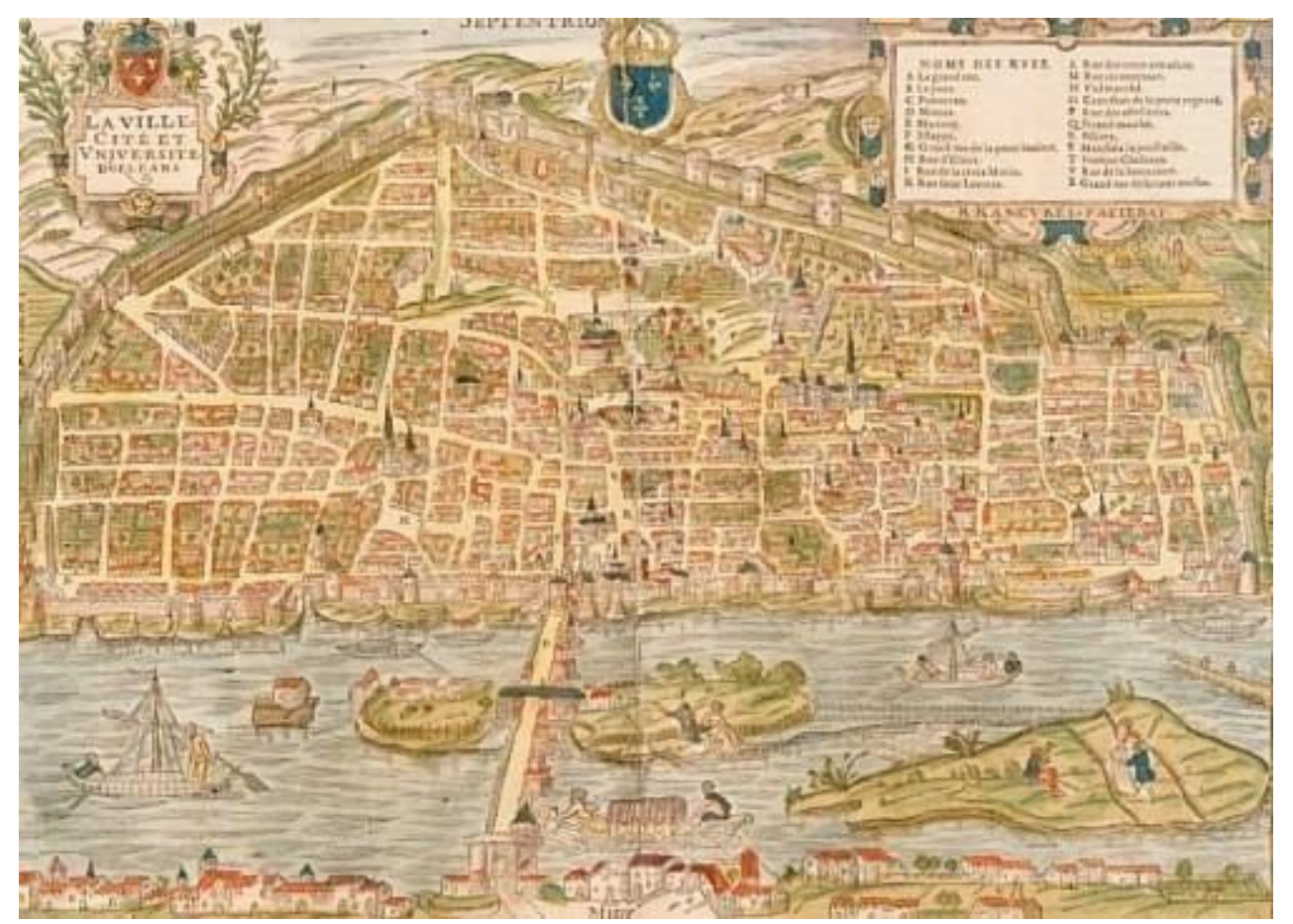

Figura 1: Mapa de Orleans

Fonte: desconhecida, Século XVI.

Observa-se a preocupação, no sécula XVI, em representar o dinamismo de 
Orleans, (França). A variedade da exploração agrícola das três ilhas, duas delas interligadas por uma ponte rústica, diversos barcos no cais e outros navegando pelo rio, além da existência de uma ponte que unia as duas margens, naquela época. O mapa cuida de mostrar o traçado das ruas, a localização de várias igrejas, algumas areas verdejantes e a existência de uma sólida muralha fortaleza protegendo a área povoada. O mapa pictórico consistia em uma forma artística de apresentar com símbolos o que desejava representar de elementos físicos, econômicos, culturais e sociais.

\section{As interfaces possíveis entre as esferas da geografia e da arte pela imaginação e pelo imaginário}

As imagens sempre estiveram presentes na relação do ser humano com o seu entorno. Elas surgem da condição humana dos sistemas perceptivos e cognitivos pelos quais captamos nosso entorno e o fazemos parte de nós. Esse papel das imagens foi entendido pela geografia humana, se inteirando de que as imagens constituíam uma maneira de abordar a relação dos homens com seu entorno ou a relação do ser humano com seu ambiente. Dito com termos mais contemporâneos, as imagens constituem uma expressão sintética da relação das pessoas com o espaço. No entendimento de Hernandez (2000, p. 133), “[...] elas são mediadoras de valores culturais e contêm metáforas nascidas da necessidade social de construir significados”.

$\mathrm{O}$ interesse pela imagem, na geografia humana, foi, gradualmente, se consolidando em torno de vários temas, como as paisagens, a percepção do espaço, a exteriorização das imagens mentais dos lugares e, também, a cartografia. Isso estimulou bastante as novas abordagens: geografia das percepções, geografia das representações, geografia cognitiva, geografia pós-colonial, entre outras. Nesse contexto, a arte pode vir a ser uma importante via de compreensão da relação ser humano-natureza em um determinado período histórico, uma vez que a expressão artística, além de ser uma expressão individual, é também a manifestação de uma dada cultura.

As possibilidades tecnológicas, contemporaneamente, contribuíram enormemente para a elaboração, a reprodução e a difusão das imagens, que se multiplicaram, exponencialmente, nas últimas décadas. Atualmente, as imagens são consideradas como forma de cimento social, uma vez que no entorno delas tecem vínculos sociais, criam identificações, fazem-se aspirações e sonhos, visibilizam as alteridades, conhecem os lugares distantes ou próximos, objetivam a apropriação de 
espaços, entre muitas outras possibilidades.

Também há a considerar, no mesmo período, a fecunda contribuição de pensadores que integraram a imaginação e o imaginário em suas análises e reflexões: Jean-Paul Sartre (2006), Jacques Lacan (2001), Cornelius Castoriadis (2007), Gilbert Durand (1981, 1994), Gaston Bachelard (1965). Eles reivindicaram a subjetividade e a imaginação como capacidades inerentes à condição humana e como inerentes ao ser-nomundo. Bachelard, para exemplificar, na sua análise sobre a poética do espaço, articula os imaginários à vida cotidiana e aos seus espaços.

Para Lindón e Hiernaux (2012), a integração da dimensão do imaginário na geografia, na análise geográfica, se deve à necessidade premente no contexto da renovação e revisão de seu objeto de estudo. Brevemente, é assumir que o espaço não se reduz a simples materialidade. Para esses autores, o imaginário, na geografia, pretende dar conta de "um aspecto intrínseco ao social, de essência imaterial, porém que se materializa. Portanto, o imaginário é parte do social e do espacial” (LINDÓN; HIERNAUX, 2012, p. 17).

Claval (2012) nos alerta que, quando os geógrafos abordam o imaginário, destacam as representações, em especial aquelas que se referem ao ambiente, às paisagens, às formas do entorno construído, aos lugares de trabalho, dos intercâmbios, das distrações e férias. Elas lhe interessam porque tratam do real - na maioria das vezes, da experiência vivida -, porém a experiência também o transfigura. As representações incitam a transformar o real, a reformulá-lo, a vê-lo de novo ângulo: "O imaginário permite captar, em filigrana, por detrás do que é, o que pode ser e o que deve ser" (2012,

p. 32). Esse autor (2004), em publicação anterior, já havia afirmado que o imaginário tem um lugar essencial na vida social porque institui os sistemas de normas que orientam a ação humana e conduzem os indivíduos e grupos sociais a projetarem o futuro e mesmo a modelá-lo.

Pinheiro et al. (2016) argumentam que o imaginário constitui-se no conjunto de representações, crenças, desejos, sentimentos, em termos dos quais o indivíduo ou um grupo de indivíduos vê a realidade e a si mesmo; também, ele compõe essa identidade e esse território e é, ainda, um ramo basilar da culturalidade de um povo, pois representa a essência imaterial que materializa a cultura. É o imaginário cultural que fundamenta a tradição e nessa perspectiva influi na manifestação física da cultura tanto no espaço, isto é, a delimitação cultural territorial, quanto na fabricação de utensílios integrantes da cultura. 
Para esses autores (PINHEIRO et al., 2016), a leitura da imagem se torna real quando se estabelecem relações com a realidade e o contexto presente ou oculto na imagem, na tentativa de compreendê-la e resolvê-la. É um momento criativo e imaginário de transformação e criação, criar autentica o ser, altera o seu cotidiano. $\mathrm{O}$ reconhecimento de ser e estar nos remete ao sentimento de pertencimento. Acerca dessa amplitude ao ler a imagem, Hernandez (2000, p. 196) ressalta “a incorporar os elementos estéticos presentes, com a finalidade de ensinar a olhar esteticamente, aprender a utilizar procedimentos de representação, interpretação do meio e valorizar as intervenções ambientais".

Santos (2002, p. 24) afirma que a geografia necessitou, desde as suas origens, de recursos comunicacionais de leitura e descrição do território. Ela principiou com relatos e desenho dos mapas, como aquele da figura 1. Com o desenvolvimento de novos olhares lançados às paisagens sucessivamente transformadas, esses recursos tornaram-se mais complexos. Os relatos, os desenhos e as pinturas; mais tarde a fotografia e o cinema; e, por último, "o vídeo e a computação gráfica constituem instrumentos de tradução do espaço, da prática do jogo entre o real e o seu significado”.

\section{A natureza da/na arte}

O representacionalismo é a mais antiga concepção sobre a natureza da arte, sugerindo que a sua função é a de representar alguma coisa. Platão e Aristóteles concebiam a arte como imitação ou mímese, ou seja, uma representação naturalista da realidade. Assim, a pintura imita a natureza, o drama imita a ação humana. Essa concepção já era problemática na Antiguidade. Um quadro que intenta copiar a realidade é chamado pejorativamente de Trompe d'oeil e geralmente é visto como alguma coisa sem valor estético.

Uma outra versão do representativismo denominou-se de neorepresentacionalismo. Nessa versão, não é mais exigido que a obra de arte represente nada, mas que seja sobre algo, que possua um tema, um assunto, um significado, que nos diga alguma coisa. Mais tecnicamente: uma obra de arte precisa ter algum conteúdo semântico. Com efeito, toda obra de arte admite ser interpretada, e, se ela admite ser interpretada, é porque ela nos toca, e, se ela nos diz algo, é porque possui algum conteúdo semântico. Esse conteúdo semântico não costuma ser convencionalmente estabelecido, o que o torna aberto, polissêmico. Mesmo uma obra de arte que pretenda ser sem 
significado algum paradoxalmente acaba por tematizar algo, a saber, a sua ausência de significado; portanto ela significa a ausência de significado.

O neo-representacionalismo é questionado e considerado como insuficiente e pobre como meio de esclarecer o que é arte, pois o que ele oferece é apenas uma condição necessária e não uma condição suficiente para a identificação da obra de arte. Todavia, muita coisa que possui conteúdo semântico não é arte.

\section{As paisagens do geógrafo e do artista}

A discussão sobre a paisagem feita em 1988 por Simmel (2009) aponta que esta, na sua origem, se vincula à existência da natureza. De fato, para sua criação foi necessária a separação do sentimento unitário da grande natureza. Foi possível o recorte da paisagem na natureza no universo pós-medieval, sendo confirmada, principalmente, com o nascimento da pintura. A noção de paisagem, sob o ponto de vista da estética, modificou- se na história, sendo ignorada, apreendida, contemplada e até servindo como pano de fundo para as manifestações artísticas contemporâneas. Sem dúvida, o gosto pela paisagem teve um surgimento tardio.

Na sua criação, destaca-se a pintura holandesa, na qual um dos gêneros que se tornou característico no século XVII foi a pintura de paisagem. Nela, há registros de diversas paisagens campesinas ou urbanas realizadas como um "espelho fiel" à realidade, em que estão ausentes as alegorias e oferecem para nós espectadores a beleza de simplesmente observar o mundo como ele é. Desse modo, as paisagens naturais tomam um lugar de destaque na arte e vêm a ocupar o primeiro plano de uma tela como temática principal e não mais como um pano de fundo, sendo assim a natureza um objeto a ser apreendido, artisticamente e por si mesmo.

Marquez (2006) considera que a paisagem é uma instância em que o tempo não é ativo, é apenas um vestígio. No seu entendimento, em seu congelamento dissimulado, a paisagem é um mapa de ações e formas. E essa ideia a autora complementa com Claval, que afirma que a paisagem é operativa. Tal afirmação traz uma abordagem da paisagem como intencionalidade e os homens como agentes produtores de sentido, gerando uma espécie de semiosfera. Essa concepção é distinta da visão clássica da paisagem como realidade objetiva, biosfera (CLAVAL, 2004).

O uso de imagens é muito significativo no ensino e na comunicação da Geografia. A forma como são percebidas as paisagens, as cidades e a sociedade nos ajuda 
a compreender as ações que as transformaram ao longo do tempo. A Geografia tem se utilizado cada vez mais desta variada oferta de imagens em seus estudos.

De fato, França (2013) pondera que uma paisagem pode trazer muitas informações sobre a geografia ou a flora de uma dada região. A diversidade de imagens e técnicas em sua produção poderá aportar, também, o ponto de vista do criador, as suas prioridades e muito de sua cultura. Como dito por Simon Schama (1996, p. 17):

É evidente que o próprio ato de identificar (para não dizer fotografar) o local pressupõe nossa presença e, conosco, toda a pesada bagagem cultural que carregamos. [...] Afinal, a natureza selvagem não demarca a si mesma, não se nomeia.

Ou seja, a paisagem é uma construção cultural sobre um ambiente natural. E por causa disso a sua significação é cambiante e a sua definição pode ser tão fluida.

A paisagem retratada em qualquer dos campos das Artes Visuais reflete o cotidiano de uma sociedade, em um determinado espaço, em um dado momento, possibilitando diferentes interpretações de significados e representações nela inseridas.

De acordo com Claval (2014, p. 323), “a paisagem é, na maioria dos casos, um reduto não planejado da atividade humana”. A partir do momento em que a paisagem se torna um objeto de contemplação e é valorizada por razões estéticas, as relações dos grupos com o espaço mudam de natureza. Às preocupações com as funcionalidades econômica e social e às mensagens simbólicas localizadas acrescenta-se uma dimensão simbólica global. As paisagens trazem a marca das culturas e, ao mesmo tempo, as influenciam, como nos diz Berque (1990). As sociedades não têm existência fora do meio em que se instalaram. Os homens e o espaço são as duas faces de uma mesma realidade e devem ser apreendidos pelo mesmo procedimento intelectual. É assim que o estudo das paisagens constitui um dos capítulos fundamentais da geografia cultural aquele que estuda a mediação pela qual os grupos humanos asseguram sua posse sobre o espaço e se submetem à sua influência (BERQUE, 2000,2016 ).

Para Besse (2016), a paisagem é produto das interações, das combinações entre um conjunto de condições e de constrições naturais (geológicas, morfológicas, botânicas etc.) e um conjunto de realidades humanas, econômicas, sociais e culturais.

Uma leitura com mais ênfase na dimensão cultural da paisagem nos apresenta Nogué (2012), referindo-se a esta como "uma projeção cultural da sociedade”, "dinâmico código de símbolos" e ainda afirmando que "a paisagem é cultura e, justamente por isso, 
é algo vivo, dinâmico, e em contínua transformação, capaz de integrar e de assimilar com o tempo modificações territoriais importantes, nos falando de cultura de seu passado, de seu presente, e talvez, também do seu futuro” (NOGUÉ, 2012, p. 129). Nogué, contudo, afirma que vemos as paisagens que "desejamos" ver, quer dizer, não vemos aquelas que se contrapõem à nossa ideia de paisagem construída socialmente. Ou seja, buscamos na paisagem aqueles modelos e padrões que se ajustam ao que temos no nosso inconsciente coletivo. É por isso que algumas paisagens periféricas são invisibilizadas a determinados grupos e classes sociais.

Andreotti (2008) comenta o quanto a definição de paisagem é complexa. A autora destaca que o conceito paisagem na geografia originou-se do seu emprego pela primeira vez por Humboldt nos decênios iniciais do século XIX. A geografia desde então incorpora a influência do homem no ambiente, evidenciando a ação do homem sobre o espaço e a paisagem. E enfatiza Andreotti: “in questo momento, la geografia ruba il concetto di paesaggio alla pitura. Ruba il concetto che, tutavvia, non è un'ipostasi di quello pittorico" (2008, p. 17). Para ela, deve-se atentar para a existência de uma paisagem cultural, além da paisagem tout court. A paisagem é genérica: por isso basta a interpretação do homem. Já a paisagem cultural, ao contrário, tem ânima, e, diante dela, intuímos a íntima conexão com as várias formas da vida espiritual que a gerou.

Andreotti (2008) atribui ao alemão Herbert Lehmann uma expressiva contribuição para desenvolver procedimentos que permitissem uma abordagem psicológica das paisagens, com a obra Formas de experiência do espaço paisagístico no espelho da arte figurativa (1967). Ressalta-se que a inspiração desse autor foi, sobretudo, Simmel (1912-1913), com Filosofia da Paisagem já citada.

Na década de 1990, o entorno filosófico das geografias da subjetividade é variado; cresceu na geografia essa corrente pelo viés da sensibilidade, mesmo que seja somente pelos aspectos estéticos. Paisagem produz estímulos que deveriam vir da complexidade da obra humana e da paisagem em si, como algo visível, e da interação deles com a psique e com toda a riqueza cultural do homem. O sujeito deve tirar suas conclusões da elaboração do todo pessoal e original da sua própria experiência. A essa relação Lehmann denominou de "aparência visual integrada”.

Segundo Simmel (1988), para termos consciência de vermos a paisagem, é preciso que os elementos da natureza, singulares do campo de visão, cativem, atraiam nosso espírito; também é preciso apreender um conjunto, uma unidade, não apenas sua justaposição sobre uma porção de solo terrestre. Além disso, é necessário ir além do que 
alcança com o olhar, chegando-se ainda à paisagem de maneira aproximada por meio do artista, que cria a paisagem na arte pictórica. O pintor exerce papel fundamental na interpretação da natureza por meio do olhar aguçado e artístico dele, conforme já o disse, para construir outra paisagem.

A paisagem na arte teve várias concepções, usos, funções no tempo e nas técnicas. Não cabe aqui fazer uma revisão histórica, e destacarei alguns que possam ilustrar a discussão proposta.

Ferreira (2014) comenta que, no apogeu do Renascimento, com Leonardo da Vinci (1452-1519), a figura humana deixou de ser protagonista para tornar-se um elemento a mais na paisagem. $O$ gênero paisagem evoluiu rapidamente, sendo consideradas as realizadas por Ticiano Vecellio (1473-1490) e Tintoretto-Jacopo Comin (1518-1594) as mais belas paisagens da história da pintura. A paisagem foi realista com Masaccio, metafísica com Uccello, geométrica com Piero della Francesca, linear e simbólica com Botticelli, fantasiosa e poética com Piero di Cosimo, com Mantegna adquiriu o valor de documento histórico, enquanto que com Giovanni Bellini se ateve à descrição direta da natureza.

É importante também citar o impacto das obras, em especial as paisagens de Hieronymus Bosch - realistas nos detalhes, mas surrealistas no conjunto -, assim como Pieter Brueghel, que teve suas paisagens divulgadas por toda a Europa, de acordo com as reflexões constantes na História e beleza da arte paisagem (2012).

A pintura de paisagem se tornou característica na pintura holandesa do século XVII. Nela, há registros de diversas paisagens campesinas ou urbanas realizadas como um "espelho fiel” à realidade para oferecer a beleza de simplesmente observar o mundo como ele é. Desse modo, as paisagens naturais tomam um lugar de destaque na arte e vêm a ocupar o primeiro plano de uma tela como temática principal e não mais como um pano de fundo, sendo assim a natureza um objeto a ser apreendido, artisticamente e por si mesmo (FRANÇA, 2013).

A partir do dispositivo teatral, a relação entre percepção e pensamento é promovida, uma vez que a Terra é apresentada como um todo do qual o ser humano participa; ela é a imagem, e o homem é aquele que a contempla e também é visto. Tal circunstância é representada na série "Grandes Paisagens (1560)", de Pieter Brueghel, o Velho, em que inclui elementos dos detalhes corográficos e topográficos, físicos, construídos ou naturais, e culturais como experiência visual do mundo terrestre. Ele mostra a terra constituída como espetáculo observado, objeto contemplado, em que 


\section{7:}

coloca em cena uma "relação visual entre o mundo e um olhar", um recurso teatral. A superfície da terra é claramente uma imagem a ser contemplada, nos afirma Besse (2006).

Um exemplo de como Brueghel situa o observador para a contemplação da paisagem pictórica encontra-se em "Caçadores na neve", que integra a série "Grandes Paisagens", datada de 1565 (figura 2). O tema principal dessa obra é a paisagem, que se desdobra em três planos: primeiro plano, plano intermediário e plano de fundo. Tudo faz menção ao inverno, com o branco do gelo dominando. A pintura foi feita de maneira que a contemplação goze de um ângulo de visão favorável, uma vez que o observador tem uma perspectiva de um local afastado e mais elevado que a cena.

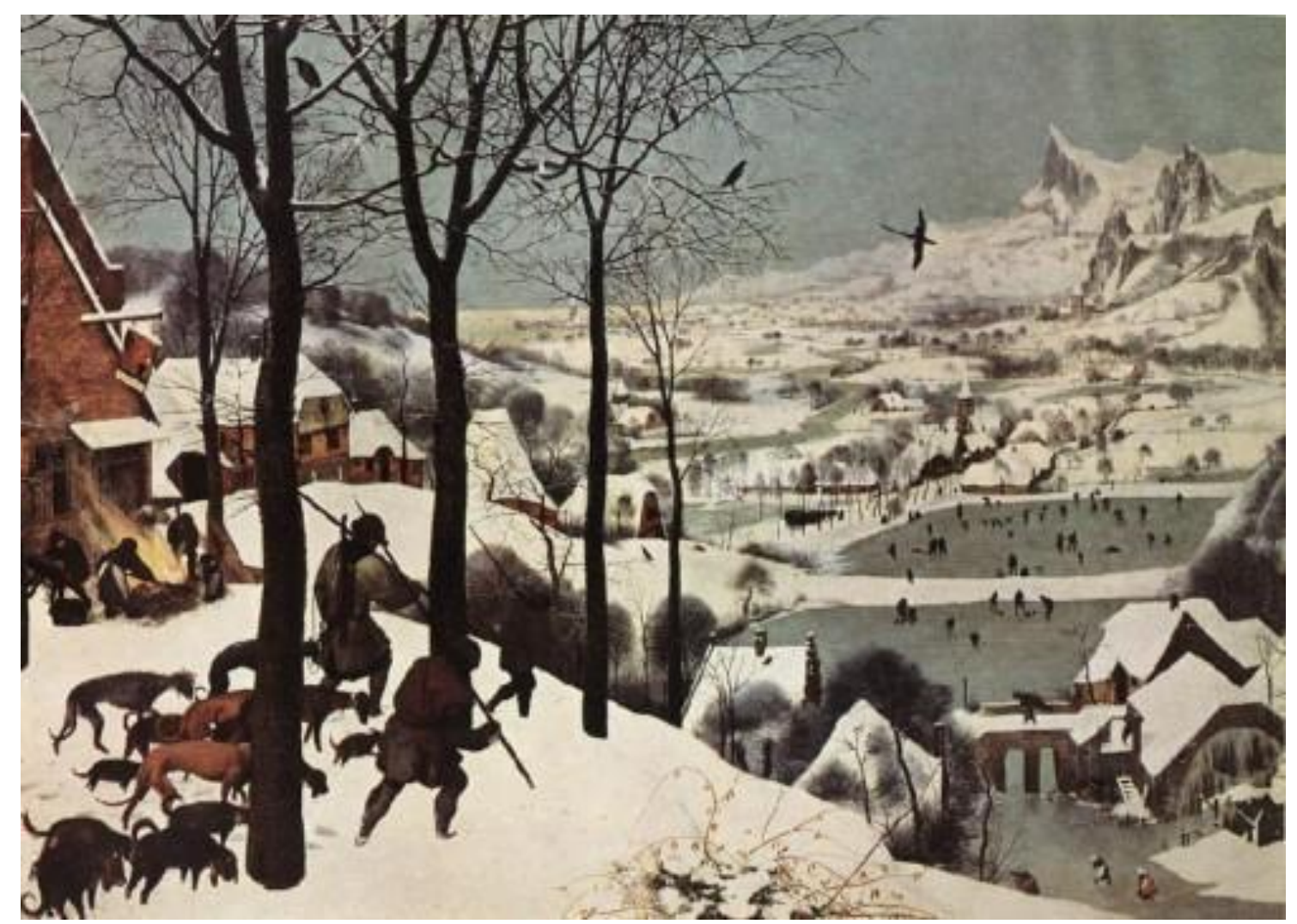

Figura 2: Bruegel. "Os caçadores na neve" (Janeiro) 1565, óleo sobre painel, 117 x 162 cm, Kunsthistorisches Museum, Vienna.

Fonte: http://www.auladearte.com.br/historia_da_arte/brueghel.htm\#ixzz3pIElo1I2.

A inspeção atenta de "Caçadores na neve" revela grandes detalhes sobre a paisagem. No fundo, apresenta montanhas e pistas. Já no plano intermediário ou central há uma aldeia, com um número significativo de edifícios espalhados pela cena e quase completamente cobertos de neve. Nela, os moradores são vistos em variadas atividades. Contudo, a maioria das pessoas, representadas com meros sinais pretos, encontra-se praticando esportes de inverno em dois lagos congelados. O artista representa com 
maestria a atmosfera de frio e de silêncio propícia a uma paisagem invernal.

Em primeiro plano, são três caçadores e sua matilha no topo da colina realizando a difícil caminhada pela neve densa em meio a quatro árvores perfiladas, desprovidas de folhas em razão do rigor invernal e com poucos pássaros. Cerca de uma dúzia de cães acompanha os homens, deixando profundos rastros atrás. À frente do grupo, veem-se os passos de uma lebre montanha abaixo. Os caçadores são vistos pelas costas pelo observador e, pela postura do corpo, aparentam estar muito cansados, o que até justifica outro nome pelo qual o quadro é conhecido: "O retorno dos caçadores". Abaixo dos caçadores que descem o declive nevado, atentos ao percurso, está a aldeia para onde se dirigem. A paisagem nos fala da manifestação da estação e do modo de vida durante o inverno.

A partir da década de 1860, os paisagistas Renoir, Monet, Cézanne, Manet e Pissarro começam a pintar ao ar livre. Monet foi o representante do Impressionismo, utilizou da paleta somente as cores puras - uma inovação para a época -, assim como decidiu dar importância às luzes em suas paisagens, ao contrário de se preocupar com a representação da realidade.

Cabe destacar que o artista europeu só consegue conquistar a autonomia de sua arte entre a segunda metade do século XVIII e a primeira metade do século XIX. Nesse período, que compreende os estilos Neoclássico e Romântico, o surgimento da Estética coloca as manifestações artísticas em um nível mais elevado ao atrelá-las à teoria, o que acaba por fundamentar a razão de ser da arte no espírito humano.

Ferreira (2014) ressalta, também, que o final do século XIX, início do século $\mathrm{XX}$, marcou o fim da pintura mimética da paisagem, como ficou conhecida entre $1500 \mathrm{e}$ 1900. A "morte da paisagem" coincide tanto com a evolução da pintura como com a rapidez das transformações territoriais. O surgimento do Impressionismo e de todos os movimentos artísticos que o seguiram contrasta com o ordenamento racional do espaço e do tempo que havia acontecido na pintura de paisagem até aquele momento, aponta Hall (2006).

Entre os séculos XIX e XX, a paisagem transformou-se em abstração. Paradoxalmente, a pintura do século XXI retoma a paisagem, sobretudo cenas de paisagens urbanas. Essa pintura passou a ser comumente denominada de hiper-realista (figura 3). O Hiperrealismo é um movimento pictórico surgido na década do 60, cujas técnicas aspiram a uma precisão quase fotográfica. Além disso, busca manter na pintura a conexão com a visão fotográfica do enquadramento e a tradução fiel da cena. 


\section{9:}

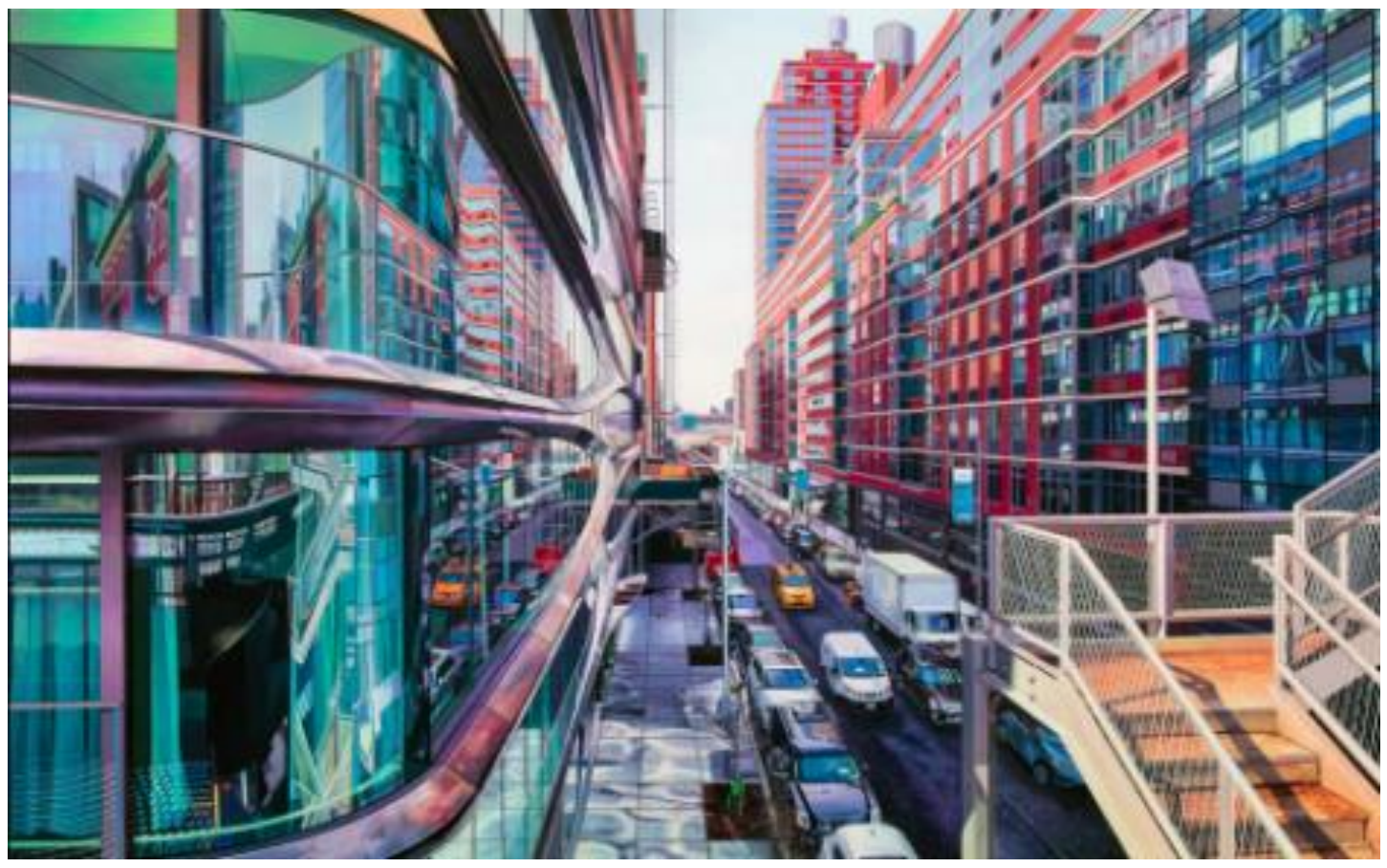

Figura 3: Nathan Walsh, View From the Highline (2020). Óleo sobre linho, 61x81cm, Clark Gallery - Boston (USA).

Fonte: https://www.artsy.net/artwork/nathan-walsh-view-from-the-highline.

A força do capitalismo e o aceleramento da globalização fizeram com que a reprodução da realidade e das paisagens nas pinturas dos séculos XIX e XX fosse esmagada. A arte passou a ser o retrato das novas estruturas sociais, e o artista pôde expressar livremente sua subjetividade. A própria figura do artista também mudou de conceito. No século XX, ele muda seu papel de observador e "reprodutor" fiel da realidade para o de um intelectual que reflete sobre a realidade (PULS, 1998). Os passos que a arte deu nos séculos XIX e XX levaram ao extremo as tensões entre a representação mental - ordem/natureza/mundo - que já estavam postas desde o século XVII, como ponderam Aliata e Silvestri (2008).

Para Kern (2011), na atualidade, a paisagem volta a ser representada de forma ampla, porém não é mais construída pela concepção antropocêntrica do Renascimento. Ela é suplantada pela técnica da máquina e dos satélites, cujas imagens informativas não se limitam a apresentar vistas surpreendentes da superfície terrestre, mas descrever detalhadamente o globo. Contudo, se na atualidade ela se transmuda e tecnifica, permanece a lembrança de que a pintura e a poesia humanizaram a paisagem.

Essas visões aéreas da Terra descartam o homem, negando ao espectador a experiência do vivido. Os novos meios técnicos suplantam a atenção do espectador em 
relação ao mundo real pelo da representação objetiva, fato que se percebe também na arte contemporânea ao privilegiar a fotografia e o vídeo. Hoje, o real é conhecido pela imagem, nos diz Jakob (2009).

\section{Apontamentos finais}

A minha intenção foi expor brevemente um diálogo possível sobre paisagem entre a geografia sociocultural e a arte e como elas transmudam a natureza em paisagem. Além disso, evidenciar a contribuição dos geógrafos, que, ao enveredarem por uma leitura sensível pela dimensão espiritual, descobrem a ideia de um outro mundo, tornamse sensíveis à representação artística daquela poética àquela das artes figurativas. A vida artística está na emoção e não na criação. A natureza adquire um valor artístico, se torna paisagem somente quando se sabe olhar como tal.

Ora, pensar a natureza, "uma construção de nossas mentes”, é pensar a interação do ser humano com o ambiente natural, sendo então as pinturas de paisagem, ao mesmo tempo uma resultante e uma via de elaboração e de expressão dessa interação. A arte traz consigo a mais íntima relação ser humano/natureza e a torna visível por ser intermediada pela imaginação. A paisagem excita a psique do observador de modo a reconhecer, perceber, sentir e vivenciar a paisagem em si; a psique interpreta sua mensagem e decifra seus significados.

Há paisagens esteticamente notáveis que são mudas para muitos de nós. Isso é possível porque essa paisagem não diz nada, não fala ao nosso espírito.

Também, neste breve estudo, ficou evidenciado que a relação geografia e arte não é nova. Para além da contaminação na geografia do século XVIII por parte das artes pictóricas e literárias, hoje as questões que atormentam tanto a geografia como as artes deixaram de basear-se em morfologias ou localizações.

Além disso, emergem outros interesses novos, como a imaginação geográfica, pela qual há a construção intelectual dos objetos que a geografia por muito tempo acreditou serem naturais. Também surge a crise de representação de paisagem arquetípica ou paisagem referencial que já não corresponderia à paisagem real. E resulta, na atualidade, de o homem viver em um mundo tão saturado de imagens, nas quais a realidade está perdendo sua substância.

De acordo com Nogué (2012), configura-se uma crise de imaginário geográfico que se manifesta por meio de um choque entre imaginários paisagísticos. 
Além disso, é possível apreender que é vasto o campo para a Geografia sociocultural estabelecer seu diálogo com a Arte sem se inquietar se o que se discute é a Arte na Geografia ou a Geografia na Arte.

\section{REFERÊNCIAS BIBLIOGRÁFICAS}

ALIATA, Fernando; SILVESTRI, Graciela. A Paisagem como cifra de harmonia: relações entre cultura e natureza através do olhar paisagístico. Curitiba: Editora UFPR, 2008.

ALPERS, Svletana. A arte de descrever. São Paulo: Edusp, 1999.

ANDREOTTI, Juliana. Per una architetettura del paesaggio. [S.l.]: Valentina Trentini editore, 2008.

ARAUJO, Andreia M. Batistta; Paisagem e arte: uma relação indivisivel. Paisagem e Ambiente, 2018, (41), p.59-82. https://doi.org/10.11606/issn.2359-5361.voi41p59-82 Acesso em 08 de dezembro 2020.

BESSE Jean .M. Ver a terra - seis ensaios sobre a Paisagem e a Geografia. São Paulo: Editora Perspectiva, 2006.

BERQUE, Augustin. La pensée paysagère. Paris: Aux éditions Éoliennes, 2016.

BERQUE Augustin. Écoumene et Médiance. Paris: Éd Belin, 2000.

BERQUE, A: Mediance, de Milieux en Paysages. coll. Géographiques, Montpellier, GIP Reclus, Ed. Belin, 1990

BRUEGEL, Pieter. Flemish. Disponível em: http://www.theartwolf.com/landscapes/bruegel-elder-hunters-snow.htm. Acesso em: 09 dez. 2020.

CARMO, Juliano S. Nelson Goodman: sobre a natureza da experiencia estética. Intuitio. Porto Alegre, 2015, vol. 8, n. 1, p. 04-14.

CAUQUELIN, Anne. Arte Contemporânea. São Paulo: Martins Fontes, 2005.

CAUQUElin, Anne. A invenção da paisagem. São Paulo: Martins Fontes, 2007.

CLAVAL, Paul. A Geografia Cultural. $4^{\mathrm{a}}$ ed. revisada. Florianópolis: Editora da UFSC, 2014.

CLAVAL, Paul. Mitos e imaginários em Geografia.In: LINDON AliciaL.HIERNAUX , Daniel(dirs) Las geografias de lo imaginário. Barcelona: Anthropos,, 2012., pp 29-48.

CLAVAL, Paul. A paisagem dos geógrafos. In: CORRÊA, Roberto Lobato; ROSENDAHL, Zeny (Orgs.). Paisagens, Textos e Identidade. Rio de Janeiro: EdUERJ, 2004, p.13-74.

DICKIE, G. “O que é arte?”. Trad. Carmo D'Orey. In: D’OREY, C. (Org.). O que é arte? 
A perspectiva analítica. Lisboa: Dinalivro, 2000.

ECO, Umberto. A definição da arte. Rio de Janeiro: Record, 2014.

FERREIRA, Luciana. Natureza, Paisagem, Geografia e Arte: Complexas Relações e Desdobramentos, no Tempo e no Espaço. Disponível em: observatoriogeograficoamericalatina.org.mx > egal 14. Acesso em: 17 dez. 2020.

FISCHER, Ernst. A necessidade da arte. Rio de Janeiro: LTC, 2007.

FRANÇA, Ana Marcela. Percepções da natureza a partir da arte: a diversidade do olhar sobre o universo natural. Dossiê História e Ambiente. Revista Cantareira, Edição 19, jul./dez., 2013.

GOMBRICH, E. H. A história da arte. Rio de Janeiro: LTC, 2008.

HALL, Stuart. A identidade cultural na pós-modernidade. Rio de Janeiro: DP\&A, 2006.

HERNANDEZ, Fernando. Cultura Visual, mudança educativa e projeto de trabalho. Porto Alegre: Artmed, 2000.

GRISON, F. Essai sur les figures géographiques dans l'art. L'espace géographique, Paris. n. 2 , p. $120-122,2000$.

JAKOB, Michael. Le paysage. Genève: Infolio, 2009.

KERN, Maria Lucia. História e Arte: as invenções da paisagem. In: Anais do XXVI Simpósio Nacional de História-ANPUH, São Paulo, julho 2011.

LINDON, Alicia,HIERNAUX, Daniel (dirs). Las geografias de lo imaginário. Barcelona: Anthropos,, 2012., p.129-139.

MARQUEZ, Renata Moreira. As Margens da imagem. In: FREIRE-MEDEIROS, Bianca; COSTA, Maria Helena Braga e Vaz da (Orgs.).Imagens Marginais. Natal: EdUFRN, 2006. p. 11-22.

NOGUE, Jan. Intervención en imaginários paisagísticos y creación de identidades territoriales. In LINDON, A..HIERNAUX, D (dirs) Las geografias de lo imaginário. Barcelona: Anthropos,, 2012., p.129-139.

PINHEIRO et al. A Arte na Geografia Cultural: explorando o Universo Emocional por meio de Imagens. Espaço e Cultura. Rio de Janeiro: Ed UERJ 2016,

PULS, Maurício. O significado da pintura abstrata. São Paulo: Perspectiva, 1998.

SANTOS, Douglas. A Reinvenção do tfspaço. São Paulo: UNESP, 2002.

SHAMA, S. Paisagem e Memória. São Paulo: Companhia das Letras, 1996.

SIMMEL, G. Filosofia da Paisagem. Covilha:Universidade da Beira Interior, 2009. 